\title{
The effect of increasing nitrogen dose, growth regulator and variety on seed and stalk yields, and some quality aspects of fibre flax
}

\author{
RIITTA SAVIKURKI
}

\begin{abstract}
SAVIKURKI, R. 1994. The effect of increasing nitrogen dose, growth regulator and variety on seed and stalk yields, and some quality aspects of fibre flax. Agricultural Science in Finland 3: 505-512. (Department of Plant Production, FIN00014 University of Helsinki, Finland. Present address: Karjatie 7, FIN-19410 Kuortti, Finland.)
\end{abstract}

\begin{abstract}
The effect of nitrogen, growth regulator and variety on seed and stalk yields and on the quality of fibre flax was studied at Kesälahti and at the Viikki Experimental Farm of the University of Helsinki, Finland, in 1987-89. The varieties tested were the domestic 'Aino' and the Dutch 'Belinka' and 'Natasha'.

Increasing the nitrogen supply from $6 \mathrm{~kg} / \mathrm{ha}$ to $30 \mathrm{~kg} / \mathrm{ha}$ inproved stalk yield significantly. The effect of the largest nitrogen dose on stalk yield was dependent on growth regulator treatment and weather conditions. Growth regulator treatment increased stalk yield when the nitrogen supply was further increased from $30 \mathrm{~kg} / \mathrm{ha}$ to $60 \mathrm{~kg} / \mathrm{ha}$. On the untreated stand, the effect of nitrogen fertilization was less strong. Increasing nitrogen supply from $6 \mathrm{~kg} / \mathrm{ha}$ to $60 \mathrm{~kg} / \mathrm{ha}$ increased branching of the stalk, crop height, technical length and thickness of stalk, lodging, 1000 seed weight and protein content. The average stalk yield at both experimental sites was $4110 \mathrm{~kg} \mathrm{DM} / \mathrm{ha}$.

In the wet and cool growing season of 1987, growth regulator treatment significantly reduced stalk length, lodging and seed yield but increased stalk yield. In the dry growing season of 1989 , growth regulator treatment increased stalk length, too.

The domestic variety, 'Aino', was the earliest but it lodged easily. Its stalk yield was the lowest, on average $3400 \mathrm{~kg}$ of DM/ha. There was no difference between the Dutch varieties, 'Belinka' and 'Natasha', both of which are suitable for growing in Finland.
\end{abstract}

Key words: Linum usitatissimum, nitrogen fertilization, variety, growth regulator, stalk yield, seed yield

\section{Introduction}

Fibre flax was an important textile fibre plant in Finland in the 1940s and 1950s, when the area under cultivation was nearly 10000 hectares (KunNAS 1982). Cultivation ceased in the 1950s, with the result that flax is almost unknown to the present generation. Interest in flax cultivation was renewed in the 1980 s along with the search for alternatives to conventional crops.
Even at the height of flax cultivation, growth areas were small and the yield qualities varied greatly. The latter caused problems to the domestic flax factory, Tampella (SEPPÄLÄ 1982), which eventually stopped buying domestic flax. Soon, growing of flax ceased altogether, and cotton and man-made fibres took the place of linen.

With the reintroduction of flax growing in the $1980 \mathrm{~s}$, it was important to focus on the quality of fibre. Even so, there have been rather few studies 
in Finland on cultivation techniques of flax and on factors affecting fibre quality (HEIKKILÄ 1989, LalluKKa 1987, PahKala 1992). Finland still has, however, a high-quality spinning and weaving industry, and revival of flax cultivation and the flax industry would create new jobs in rural areas and direct surplus field capacity to alternative, non-food production.

\section{Material and methods}

The effects of nitrogen supply, growth regulator and variety on the yield and quality of fibre flax were studied with nine experiments conducted at Kesälahti, Pertunmaa, Sonkajärvi, Viikki and Ypäjä in 1987-89.

The results of six of these experiments, those conducted at Kesälahti and Viikki in 1987-89, are discussed here. The field experiments were arranged in a split-split-plot design with three replicates. The treatments were:

nitrogen dose (main plot)

$\begin{array}{ll}\mathrm{N}_{1} & 6 \mathrm{~kg} \mathrm{~N} / \mathrm{ha} \\ \mathrm{N}_{2} & 30 \mathrm{~kg} \mathrm{~N} / \mathrm{ha} \\ \mathrm{N}_{3} & 60 \mathrm{~kg} \mathrm{~N} / \mathrm{ha}\end{array}$

growth regulator (split plot)

$\mathrm{K}_{0} \quad$ untreated

$\mathrm{K}_{1} \quad$ Cerone (ethephon $480 \mathrm{~g} / \mathrm{l}$ ) $0.7 \mathrm{l} / \mathrm{ha}$

variety (split-split-plot)

$$
\begin{array}{ll}
\mathrm{A}= & \text { 'Aino' } \\
\mathrm{B}= & \text { 'Belinka' } \\
\mathrm{C}= & \text { 'Natasha' }
\end{array}
$$

The sowing density was 2200 germinating seeds $/ \mathrm{m}^{2}$. Weeds were sprayed with either Basagran MCPA or Glean 20 DF. In addition, couch grass (Elymus repens) was controlled with Fusilade at Viikki in 1989.

Cerone was sprayed just before flowering according to the method of BODLAENDER and van der WAART (1973). Fibre flax can be harvested at different stages of ripening. Here it was harvested at the stage of yellow ripeness, 30-35 days after full flowering, using a self-propelled har- vester which pulled the flax up by the roots from a width of 1.5 metres. The harvester tied the flax into bundles of about $7 \mathrm{~kg}$, which were then dried. Seed capsules were separated from air-dry bundles by pulling the bundles through a coarse metal comb by hand. The stalk yield was then determined as $\mathrm{kg} \mathrm{DM} / \mathrm{ha}$. Separated seed capsules were threshed, and the seed yield was weighed. Based on the moisture content, the DM content of the seed yield was estimated as $\mathrm{kg} / \mathrm{ha}$.

\section{Field evaluations and statistical methods}

The time of emergence, plant density, onset of flowering, full flowering, plant height before harvesting, lodging, technical length and thickness of stalks, number of seed capsules and buds per plant were determined. The results were submitted to analysis of variance of split-split-plot design. Tukey's HSD (Honestly Significant Difference) test was used to determine the significances $(\mathrm{p}=0.05)$ of differences between group means (RANTA et al. 1989).

\section{Growing conditions}

The soil was very fine sand or sandy till, $\mathrm{pH}$ 5.66.2 at Kesälahti and $\mathrm{pH} 5.2-6.3$ at Viikki. The weather conditions during each of the growing seasons were totally different. The effective temperature sum (ETS) and precipitation are shown in Table 1.

Table 1. Effective temperature sum $\left(\right.$ ETS $5^{\circ} \mathrm{C}$ ) and precipitation in Kesälahti and Viikki in 1987-1989.

\begin{tabular}{llcc}
\hline & & $\begin{array}{c}\text { ETS } \\
5^{\circ} \mathrm{C}\end{array}$ & $\begin{array}{c}\text { Precipitation } \\
\text { mm }\end{array}$ \\
\hline 1987 & & & \\
& Kesälahti & 777 & 406 \\
& Viikki & 913 & 303 \\
1988 & & & \\
& Kesälahti & 1076 & 197 \\
& Viikki & 1145 & 210 \\
1989 & & & \\
& Kesälahti & 969 & 194 \\
& Viikki & 923 & 213 \\
\hline
\end{tabular}




\section{Results}

\section{Seedlings}

The optimal plant density, 2200 plants $/ \mathrm{m}^{2}$, was not attained in any of the trials. Flax stands germinated best in 1987 and worst in 1988. 'Aino' had the lowest number of seedlings.

\section{Flowering}

Flowering started 40-50 days after sowing, in 'Aino' 3-10 days earlier than in either 'Belinka' or 'Natasha'. In 1987, flowering was retarted by about 20 days in crops given growth regulator treatment as compared with untreated crops. Nitrogen fertilization had no effect on either the onset or duration of flowering.

\section{Technical length}

Increasing nitrogen supply from $6 \mathrm{~kg} / \mathrm{ha}$ to $30 \mathrm{~kg} / \mathrm{ha}$ significantly increased the technical length of the stalk at Viikki in 1987, whereas growth regulator treatment significantly shortened it. On average, the technical length was $50 \mathrm{~cm}$, being shortest in 'Aino'. The effect of nitrogen dose and variety on technical stalk length varied from year to year. Stands treated with Cerone growth regulator were significantly shorter than untreated stands.

\section{Stalk thickness}

Nitrogen fertilization increased stalk thickness highly significantly. 'Belinka' had the thinnest stalk $(1.15 \mathrm{~mm})$ and 'Natasha' the thickest $(1.20 \mathrm{~mm})$.

\section{Lodging}

All treatments had a very significant effect on lodging. Lodging was most severe in 'Aino'.

\section{Stalk yield}

The highest stalk yields were harvested at Viikki in 1987, $6150 \mathrm{~kg} \mathrm{DM} / \mathrm{ha}$ on average. At Kesälah- ti, the average yield was $4760 \mathrm{~kg} \mathrm{DM} / \mathrm{ha}$. Increasing nitrogen supply from $6 \mathrm{~kg}$ to $30 \mathrm{~kg} / \mathrm{ha}$ increased yield significantly at both experimental sites, but the effect varied depending on trial site and growth regulator treatment. In untreated stands, no increase was observed, but when growth regulator was used, yields increased by $2000 \mathrm{~kg}$ $\mathrm{DM} / \mathrm{ha}$ on average. Variations between varieties were significant at Viikki. The average stalk yield was $1260 \mathrm{~kg} \mathrm{DM} /$ ha smaller in 1988 than in 1987. At Viikki, the average yield was $4350 \mathrm{~kg} \mathrm{DM} / \mathrm{ha}$ and at Kesälahti $4000 \mathrm{~kg} \mathrm{DM} / \mathrm{ha}$. The effects of both nitrogen fertilization and variety were highly significant at both trial sites. Growth regulator treatment increased stalk yield at both sites, but the increases were not significant. 'Aino' had significantly lower yields than 'Belinka' or 'Natasha'.

In 1989, stalk yields were very low. At Viikki the average yield was $2500 \mathrm{~kg} \mathrm{DM} / \mathrm{ha}$ and at Kesälahti 2870 kg DM/ha. At Kesälahti, nitrogen fertilization had a highly significant effect on stalk yields, and both variety and the interaction between nitrogen fertilizing and growth regulator had a highly significant effect on stalk yield. At Viikki, only variety had a highly significant effect.

In the pooled data for the three years, the effects of all three treatments were statistically significant. F-values were $15.90^{* * *}$ for $\mathrm{N}$ fertilization, $13.55^{* * *}$ for growth regulator and $15.79 * * *$ for variety. Increasing nitrogen supply from $6 \mathrm{~kg}$ to $60 \mathrm{~kg} / \mathrm{ha}$ increased stalk yield in populations treated with ethephon. The effect of growth regulator was significant on stalk yield (Table 2).

\section{Seed yield}

Seed yields varied greatly between years. The effect of variety was strongest (Table 3$)(\mathrm{F}=$ $\left.12.93^{* * *}\right)$, followed by growth regulator $(\mathrm{F}=$ $\left.10.94^{* *}\right)$ and nitrogen fertilizer $\left(\mathrm{F}=4.35^{\circ}\right)$.

In 1987, average seed yield was $180 \mathrm{~kg} \mathrm{DM} /$ ha at Kesälahti and $600 \mathrm{~kg} \mathrm{DM} / \mathrm{ha}$ at Viikki. In 1988, seed yields averaged $700 \mathrm{~kg} \mathrm{DM} / \mathrm{ha}$ and $1050 \mathrm{~kg} \mathrm{DM} / \mathrm{ha}$, respectively. Nitrogen supply increased seed yield. In 1989, seed yields were almost equal at both experimental sites, $770 \mathrm{~kg}$ 
Table 2. Effect of increasing nitrogen doses, growth regulator and varieties on stalk yields at Kesälahti and Viikki in 1987-1989, kg DM/ha.

\begin{tabular}{|c|c|c|c|c|c|c|}
\hline \multirow{2}{*}{$\begin{array}{l}\text { Growth } \\
\text { regulator }\end{array}$} & & \multirow{2}{*}{$\begin{array}{c}\mathrm{N} \text { dose } \\
\mathrm{kg} / \mathrm{ha}\end{array}$} & \multicolumn{3}{|c|}{ Variety } & \multirow[b]{2}{*}{ Mean } \\
\hline & & & 'Aino' & 'Belinka' & 'Natasha' & \\
\hline & & 6 & 2570 & 3710 & 3560 & 3280 \\
\hline & 0 & 30 & 3210 & 4420 & 4370 & 4010 \\
\hline & & 60 & 3180 & 4230 & 4760 & 4060 \\
\hline & & 6 & 3150 & 3720 & 3810 & 3560 \\
\hline & Cerone & 30 & 3880 & 4840 & 4940 & 4550 \\
\hline & & 60 & 4350 & 5640 & 5580 & 5190 \\
\hline \multicolumn{7}{|l|}{ Means } \\
\hline & $\mathrm{O}$ & & 2990 & 4120 & 4230 & $3780^{\circ}$ \\
\hline & Cerone & & 3790 & 4730 & 4780 & $4430^{b}$ \\
\hline & & 6 & 2860 & 3710 & 3690 & $3420^{\circ}$ \\
\hline & & 30 & 3540 & 4630 & 4660 & $4290^{\mathrm{a}}$ \\
\hline & & 60 & 3760 & 4930 & 5170 & $4620^{\circ}$ \\
\hline Mean & & & $3390^{\mathrm{a}}$ & $4420^{a}$ & $4510^{\mathrm{a}}$ & 4110 \\
\hline
\end{tabular}

$\operatorname{HSD}(\mathrm{N}-$ dose $)=1513 \mathrm{~kg}$

HSD $($ variety $)=1270 \mathrm{~kg}$

HSD $($ growth regulator $)=467 \mathrm{~kg}$

HSD (Honestly Significant Difference)

Means followed by the same letter do not differ from each other statistically significantly.

$\mathrm{DM} / \mathrm{ha}$ (range $510-1230 \mathrm{~kg}$ ) and $780 \mathrm{~kg} \mathrm{DM} / \mathrm{ha}$ (range 600-980 kg DM/ha), respectively.

The average three-year seed yield was $690 \mathrm{~kg}$ $\mathrm{DM} / \mathrm{ha}$. Increasing nitrogen fertilization from 6 $\mathrm{kg}$ to $60 \mathrm{~kg} / \mathrm{ha}$ raised seed yield by $140 \mathrm{~kg} \mathrm{DM} /$ ha. 'Aino' was the poorest yielding variety. Treatment with growth regulator reduced seed yield significantly, by $120 \mathrm{~kg} \mathrm{DM} / \mathrm{ha}$.

\section{Discussion}

Weather conditions had a marked effect on the results of the experiments. Experimental year 1987 was cool and rainy, and the effective temperature sum was the lowest this century. 1988 and 1989 were warm, and precipitation was low at the beginning of the growing seasons.

\section{Plant density}

The main factor causing poor emergence was excessively wide row distance. Seeds were sown with a fertilizer drill at a row distance of 12.5 $\mathrm{cm}$. Wide distances between rows tend to increase the number of seeds $\left(2200\right.$ seeds $\left./ \mathrm{m}^{2}\right)$ competing for growing space, and thus some of the plants wither. According to a Dutch study, a distance of $4 \mathrm{~cm}$ between rows gives the most even population (Saaren Pellava Oy 1989). In our study, no increase in stalk thickness was seen when a smaller than optimum population density was used.

The smaller number of seedlings of 'Aino' than of other varieties is attributed to the poorer seed quality of 'Aino' (LALLUKKA et al. 1988, LALLUKKA and SAVIKURKI 1989, SAVIKURKI 1990). This domestic seed was mat and blotchy.

\section{Flowering}

Weather conditions affected the onset of flowering. In the damp growing season, plants grew in height, whereas in the dry growing season shortage of water restricted the growth of stalks in height but increased the number of flowering branches. Nitrogen fertilization affected neither the onset nor the duration of flowering. The same conclusions were drawn by ABDEL-RAOUF et al. 
Table 3. Effect of variety, nitrogen and growth regulator on statistical significances between seedlings, technical length, stalk thickness, stalk yield and seed yield at Kesälahti and Viikki in 1987-1989.

\begin{tabular}{ccccc}
\hline $\begin{array}{c}\text { Number of } \\
\text { seedlings }\end{array}$ & $\begin{array}{c}\text { Technical } \\
\text { length }\end{array}$ & $\begin{array}{c}\text { Stalk } \\
\text { thickness }\end{array}$ & Stalk yield Seed yield \\
\hline
\end{tabular}

Year

Experimental site

Significances

Treatment

1987

Kesälahti

Nitrogen

Growth regulator

Variety

Nitrogen \& growth regulator

Growth regulator \& variety

Viikki

Nitrogen

Growth regulator

Variety

Nitrogen \& growth regulator

Nitrogen \& variety

Growth regulator \& variety

$\begin{array}{ccccc}\text { ns. } & * * & * & * * * & \text { ns. } \\ \text { ns. } & * * * & \text { ns. } & * * * & * * * \\ * * & * * * & \text { ns. } & * * * & * * * \\ & & & & * \\ & & & & * *\end{array}$

1988

Kesälahti

Nitrogen

Growth regulator

Variety

Viikki

Nitrogen

Growth regulator

Variety

Nitrogen \& growth regulator

ns. $* * * * * * \quad * * * \quad$ ns.

ns. $\quad$ ns.

ns. ns. ns.

****

ns. $* * * * *$

1989

Kesälahti

Nitrogen

Growth regulator

Variety

Nitrogen \& growth regulator

ns.

ns.

***

*

**

ns.

$* *$

$*$

*

ns.

***

Nitrogen \& Variety

Viikki

Nitrogen

Growth regulator

Variety

ns.

ns.

***

ns.

ns.

Growth regulator

Variety

*** significant at $0.1 \%$ level

** significant at $1 \%$ level

* $\quad$ significant at $5 \%$ level

ns. not significant 
(1983). The enhancement of branching by nitrogen fertilization was also observed by MOURSI and EL-HARIRI (1977), and the retarding effect of growth regulator treatment on flowering by BoDLAENDER and van der WAART (1973). The effect of growth regulator treatment is probably influenced by the stage of development of the plant at the moment of spraying. TURNER (1987) emphasizes that ethephon should not be used in hot and dry weather when a plant is under stress.

\section{Technical length}

Technical length of stalk is a measure of flax fibre quality. According to FröIER and ZIENKIEWICZ (1982), the optimum technical length is 75 $85 \mathrm{~cm}$. This length was not attained in our study, although it was not far off at Kesälahti in 1987, when an average of $71 \mathrm{~cm}$ was obtained. The effects of cultivation techniques on technical stalk length correlated with those on stand height.

In 1987, humidity should have been sufficient to increase the length of stalks. As well as by weather conditions, length was affected by sowing density and row distance. The sowing density used should have been sufficient to form a dense stand (DANELl 1967). By shortening the row distance, there would be less competition in the population, and fewer seedlings would fail at the seedling stage (Saaren Pellava Oy 1989).

Growth regulator treatment reduced the technical length of the stalk, implying that fibres should be shorter in crops treated with growth regulator than in an untreated population. In the trials of HEIKKILÄ (1989), 'Aino' had the longest fibres at the smallest dose of nitrogen, $20 \mathrm{~kg} / \mathrm{ha}$. The findings on stalk length suggest that 'Aino' thrives on a smaller dose of nitrogen than do the other varieties.

\section{Stalk thickness}

The stalk thickness of good-quality fibre flax should be 1.1-1.5 mm (FröIER and ZIENKIEWICZ 1982). The effect of cultivation techniques on stalk thickness in our study was insignificant. Increasing the nitrogen dose from $6 \mathrm{~kg} / \mathrm{ha}$ to $60 \mathrm{~kg} /$ ha increased stalk thickness by $0.16 \mathrm{~mm}$ on average. Similar results were obtained by VASILICA (1971).

According to FröIER and ZIENKIEWICZ (1982), stalk thickness exceeding $2 \mathrm{~mm}$ would result in lower fibre yield and coarser fibre. GAD and ELFAROUK (1978) observed that the fineness of fibre was significantly reduced at nitrogen doses exceeding $35 \mathrm{~kg} / \mathrm{ha}$.

Plant density did not explain the variations in stalk thickness either. At Viikki, the lowest population density $\left(1200\right.$ plants $\left./ \mathrm{m}^{2}\right)$ led to the thinnest stalk (0.98 mm). El-Hariri (1968) and ElNKHLAWY (1975) had similar results, and concluded that the fineness of the fibre did not depend on plant density. GAD and EL-FAROUK (1978), in contrast, claim that population density does have a significant effect on fibre fineness.

\section{Stalk yield}

Fluctuations of yields are attributable to the difference in weather conditions between the growing seasons. Drought reduced stalk yield.

The lowest stalk yields were obtained in the trials with the lowest plant density. According to BALAzs et al. (1986), if plant density is increased from 2000 plants $/ \mathrm{m}^{2}$ to 2400 plants $/ \mathrm{m}^{2}$, both stalk yield and fibre yield will also increase.

The need for nitrogen fertilization has been considered small throughout the history of Finnish flax cultivation. The findings of this study give no cause to change this view to any marked extent. Increasing the nitrogen supply during a damp growing season increased the stalk yield, but lodging hindered harvesting, and part of the lodged crop had to be left on the ground (LALLUKKA 1987, LALLUKKA et al. 1988). In dry growing seasons, nitrogen fertilization does not significantly increase stalk yield, and there is no economic benefit from using much nitrogen fertilizer.

With large doses of nitrogen, high yields and successful harvesting could be guaranteed when growth regulator was used. However, as noted when flax from the 1987 trials at Viikki was retted, broken, scutched and spun into year, growth 
regulator had an unfavourable effect on the quality of the fibre. The highest stalk yield, $9510 \mathrm{~kg}$ $\mathrm{DM} / \mathrm{ha}$, gave the lowest fibre yield, $520 \mathrm{~kg} / \mathrm{ha}$.

The variety used here was 'Natasha', which had been treated with growth regulator and with a nitrogen dose of $60 \mathrm{~kg} / \mathrm{ha}$. The heaviest fibre yield $(24 \%)$ was obtained from the 'Belinka' population, which was not treated with growth regulator but had received a nitrogen dose of $30 \mathrm{~kg} /$ ha (LALLUKKA and SAVIKURKI 1989).

\section{Seed yield}

Weather conditions affected seed yields at both trial sites, yields being smaller in a cool and wet year than in a dry year.

Increasing nitrogen supply from $6 \mathrm{~kg} / \mathrm{ha}$ to 60 $\mathrm{kg} / \mathrm{ha}$ increased the average seed yield. However, in 1987 the seed yield decreased with the largest nitrogen dose. At harvest, the seed was not fully mature, as growth regulator treatment had delayed ripening. Cerone had a retarding effect on development, and the cool and rainy weather that summer may have further impaired flowering. This was most clearly seen in late varieties.

Excessive drought may also destroy seed yield. Rains following the actual flowering season at the end of July revived the population, leading to new growth and flowering. Thus, by the time of harvest the seed yield was not yet ripe (SAVIKURKI 1990). The adverse effect of growth regulator treatment on seed yield is due to its retarding effect (MADDENS 1977, TURNer 1987). In our study cultivation techniques had hardly any effect on the quality of seed yield. The germinability of the seed estimated from the 1989 yield proved that under good conditions fibre flax produces a seed yield good enough for sowing.

Weather conditions appeared to have a greater influence on the quantity and the quality of fibre flax yield than did cultivation techniques. In 1987, a year of general crop failure, flax gave the best stalk yield, but the seed yield was non-existent. Growing of flax should therefore be concentrated on areas where precipitation in June is closer to $90 \mathrm{~mm}$ than to $40 \mathrm{~mm}$, where hydrological conditions are balanced and where the soil is fine sand or sandy till. The capillary rise of water is higher in sandy soils than in clay soils. Harmful effects of drought can be prevented by irrigation when the stalk grows in height.

The most suitable nitrogen dose found in this study was $30 \mathrm{~kg} / \mathrm{ha}$. In practice, depending on the soil type, variety and weather conditions, a nitrogen dose of between 20 and $50 \mathrm{~kg} / \mathrm{ha}$ would produce the best results in terms of quantity and quality of yield.

Our trials indicate that ethephon growth regulator should be used only on lush populations, when precipitation in May-June is higher than normal and severe lodging would threaten successful harvesting. The correct timing of ethephon growth regulator treatment requires further study, however.

The experiment proved that the foreign varieties of fibre flax, 'Belinka' and 'Natasha', are suitable for growing in Finland, as they give heavier yields and better properties of stalk than the domestic variety, 'Aino'. Seed production with the foreign varieties seems to be possible in Finland.

\section{References}

Abdel-Raouf, M.S., El-Hattab, A.H., Gheith, E.M.S. \& Shaban, A.SH. 1983. Effect of $\mathrm{N}$ level on flowering, seed and fiber yield of some introduced and local flax varieties. Annals of Agricultural Science. Moshtohor 19, 1: 69-78.

Balazs, F., Ionescu, S. \& Doucet, M. 1986. Contributions on the stabilization of sowing techniques for fibre flax in eastern Transsylvania. Probleme de Agrofitotehnie Teoretica si Aplicata 8, 4: 331-344.
Bodlaender, K.B.A. \& WAart, M. van der, 1973. The influence of growth regulating substances on growth and yield of flax. Fibra 18, 2: 4-26.

DANELL, N. 1967. Försök med spånadslin. Lantbr.högsk. Medd. A 77: 1-18.

EL-HARIRI, D.M. 1968. Factors affecting quality of flax yield. Ph.D. Thesis, Fac. Agr. Ain Shams Univ.

EL-NKHLAWY, F.S. 1975. Effect of some cultural practises on flax. M.Sc. Thesis. Fac Agr. Alexandria Univ. 
FröIER, K. \& ZiEnKIEWICZ, H. 1982. Linboken. 159 p. Centraltryckeriet $\mathrm{Ab}$. Borås.

GAD, A.Y. \& EL-FAROUK, M. 1978. Influence of seeding rates and nitrogen levels on yield and some technologigal characters of flax. Agricultural Research Review 56, 8: 79-91.

HEIKKILÄ, R. 1989. Kuitupellavaa viljelemään. Koetoiminta ja Käytäntö 46: 31 .

KUNNAS, R. 1982. Pellavan viljely - pelkkää nostalgiaako. Maataloushallinnon Aikakausikirja 4: 13-19.

LALLUKKA, U. 1987. Kuitupellavan kokeilua Viikissä. Käytännön Maamies 37, 4: 24-25.

-, KURKI, V. \& SAVIKURKI, R. 1988. Kuitupellavan tuotanto- ja käyttömahdollisuudet Suomessa sekä loppuraportti kuitupellavan viljelyteknisestä tutkimuksesta vuonna 1987. Helsingin Yliopisto. Kasvinviljelytieteen laitos. Julkaisuja n:o 18. 48 p. Helsinki.

- \& SAVIKURKı, R. 1989. Kuitupellavan viljelyteknisiä tutkimuksia vuonna 1988 sekä viljelytekniikan vaikutus kuitupellavan kuidun määrään vuonna 1987. Helsingin yliopiston kasvinviljelytieteen laitos. Julkaisuja n:o 22. 36 p. Helsinki.

MadDENS, K. 1977. Prevention of lodging in fibre flax using the growth regulator ethephon. Revue de l'Agriculture 30, 4: 881-905.

Moursi, M.A. \& El-Hariri, D.M. 1977. Effect of Ammo- nium nitrate and Irrigation frequency on flax yield. Egyptian Journal of Agronomy 2, 1: 61-69.

PAHKALA, K. 1992. Linodling och forskning i Finland. Nordisk Linkonferanse. NLVF Energy office, Ås, Norge. Mimeogr. 98 p. (Available at Agricultural Research Centre of Finland, Institute of Crop and Soil Science.)

RantA, E., Rita, H. \& KoukI, J. 1989. Biometria. Tilastotiedettä ekologeille. 569 p. Yliopistopaino, Helsinki.

Saaren Pellava Oy. 1989. Pellavan tuotanto. Cebeco Zaden B.V. Mimeogr. 8 p. (Available at Saaren Pellava Oy, Saari.)

SAVIKURKI, R. 1990. Raportti kuitupellavan (Linum usitatissimum L.)viljelyteknisestä tutkimuksesta vuonna 1989. Suomen Pellava ry. Iisalmi. Mimeogr. 36 p. (Available at Ylä-Savon Instituutti, Sonkajärvi.)

Seppälä, R. 1982. Pellavan tarina. Pellava Säătiö. 72 p. Tampere.

TURner, J. 1987. Linseed Law. A Handbook for Growers and Advisers. 356 p. Ispswich.

VAsilicA, C. 1971. Experimental results on the effect of complex of factors - fertilizer application $\mathrm{x}$ variety $\mathrm{x}$ plant density - yield of fibre flax grown in N.W. Moldavia. Lucrari Stiintifice: 297-304.

\title{
SELOSTUS
}

\section{Typpilannoituksen, kasvunsääteen ja lajikkeen vaikutus kuitupellavan varsi- ja siemensatoon sekä varsisadon ulkoisiin laatutekijöihin}

\author{
RIITTA SAVIKURKI
}

Helsingin yliopisto

Tutkimuksessa selvitettiin kuitupellavan viljelytekniikkaa Kesälahden Mäntyniemessä ja Helsingin yliopiston Viikin koetilalla vuosina 1987, 1988 ja 1989. Tarkastelun kohteena olivat typpilannoitus, etefoni-kasvunsäådekäsittely ja kotimainen Aino- sekä hollantilaiset Belinka- ja Natasha-lajikkeet.

Kasvustosta havainnoitiin varsi- ja siemensadon lisäksi sadon ulkoista laatua kuvaavat ominaisuudet kuten taimettuminen, varren haaroittuminen, kukinta, kasvuston pituus, varren tekninen pituus, varren paksuus, lakoutuminen, tuhannen siemenen paino ja siementen valkuaispitoisuus.

Typpilannoituksen lisääminen $6 \mathrm{~kg}$ :sta $30 \mathrm{~kg}$ :aan/ha lisäsi varsisatoa. Suurimman typpiannoksen vaikutus varsisatoon riippui kasvunsäädekäsittelystä ja kasvukauden säästä. Kasvunsääteellä käsitellyssä kasvustossa varsisato lisääntyi typpilannoitusta lisättäessä $30 \mathrm{~kg}$ :sta/ha $60 \mathrm{~kg}$ :aan/ ha. Sen sijaan käsittelemättömässä kasvustossa typpilannoituksen vaikutus ei ollut yhtä voimakas. Typpilannoi- tuksen lisääminen $6 \mathrm{~kg}$ :sta $60 \mathrm{~kg}$ :aan/ha lisäsi varren haaroittumista, kasvuston pituutta, varren teknistä pituutta, varren paksuutta, lakoutumista, tuhannen siemenen painoa ja valkuaispitoisuutta. Vaikutuksen voimakkuus riippui vuoden säästä. Varsisato molemmilla koepaikoilla oli keskimäärin $4110 \mathrm{~kg} \mathrm{ka/ha}$. Kosteana ja viileänä kasvukautena 1987 kasvunsääteen käyttö lyhensi varren pituutta sekä vähensi kasvuston lakoutumista ja siemensadon määrää. Samalla kasvunsääde lisäsi varsisatoa. Sadonlisäykset olivat suurimmat, kun typpilannoitus oli runsain. Vähäsateisena kasvukautena 1989 kasvunsääteen käyttö jopa lisäsi varren pituutta.

Kotimainen Aino-lajike oli aikaisin, mutta herkästi lakoutuva. Sen varsisadot olivat alhaisimmat, keskimäärin $3400 \mathrm{~kg} \mathrm{ka} / \mathrm{ha}$. Ulkomaiset lajikkeet Belinka ja Natasha osoittautuivat hyvin tasaveroisiksi lajikkeiksi.

Viileänä kasvukautena 1987, jolloin kasvin tuleentuminen myöhästyi, siemensato oli keskimäärin vain 390 kg ka/ ha, kun se vuosina 1988-89 oli keskimäärin $840 \mathrm{~kg} \mathrm{ka} / \mathrm{ha}$. 